\title{
Cost Efficiency of Building Information Modeling use at the Stage of Real Estate Object Maintenance
}

\author{
Tatyana Kisel ${ }^{1 *}$ \\ ${ }^{1}$ Moscow State University of Civil Engineering, 129337, 26, Yaroslavskoye Shosse, Moscow, Russia
}

\begin{abstract}
Formation of the digital economy is the main direction of many countries' development and the trend of the whole world's economic development. According to research results, a low level of digitalization in the construction industry is noted. The construction industry is a significant part of the world economy. Construction makes up 13\% of the world's GDP. Such scales of the industry allow us to conclude that its digitalization can bring considerable results. The basis of digitalization in construction is the application of building information modeling (BIM) at all stages of a real estate object life cycle. This research is devoted to studying the conditions and methods of the assessment of cost efficiency of BIM application at the real estate object maintenance stage. The method of calculation of the managing company savings from the application of an information model during real estate object maintenance is offered as the result of the research. The author analyzed various models of maintenance performance for the specification of the offered calculation procedure. The main direction of receiving the budget funds economy in a managing company is the reduction of time spent on the corresponding works and, respectively, the reduction of financial expenses connected with the compensation. Also, BIM application during construction leads to a decrease in the number of breakages of the engineering equipment at the maintenance stage. This means that the economy of material inputs will take place.
\end{abstract}

Keywords: Building information modeling; Construction; Cost reduction; Maintenance; Managing company

\section{Introduction}

Digital technologies have strongly entered all spheres of human activity. They have a considerable impact on economic processes and transform the world economy. The socalled digital economy is formed as a result. Despite the novelty of the term and the availability of various approaches to the determination of the concept of the digital economy (their brief characteristics are presented in Table 1), it can be defined in the most generalized way as the economy based on digital technologies with the prevalence of use of information in its electronic form at all stages (creation, transfer, processing, application, and storage). This transformation of the economy is promoted by several factors:

*Corresponding author's email: SilantievaTN@mgsu.ru, Tel.: +7-915-2655500; Fax: +7-495-6518182 doi: 10.14716/ijtech.v12i7.5382 
Table 1 Some approaches to the determination of the concept of the digital economy

\begin{tabular}{|c|c|c|}
\hline No. & Definition of "Digital Economy" & Feature of the Approach \\
\hline 1 & $\begin{array}{l}\text { The digital economy is the economic activity that results from billions of } \\
\text { everyday online connections among people, businesses, devices, data, and } \\
\text { processes. The backbone of the digital economy is hyperconnectivity, which } \\
\text { means the growing interconnectedness of people, organizations, and } \\
\text { machines that results from the Internet, mobile technology, and the Internet } \\
\text { of things (IoT) (Cassar et al., 2010). }\end{array}$ & $\begin{array}{l}\text { Emphasis on the growing } \\
\text { interrelation among people, } \\
\text { organizations, and machines } \\
\text { due to connections by means } \\
\text { of the Internet }\end{array}$ \\
\hline 2 & $\begin{array}{l}\text { The digital economy incorporates all economic activity reliant on or } \\
\text { significantly enhanced by the use of digital inputs, including digital } \\
\text { technologies, digital infrastructure, digital services, and data. It refers to all } \\
\text { producers and consumers, including the government, that are utilizing these } \\
\text { digital inputs in their economic activities (OECD, 2020). }\end{array}$ & $\begin{array}{l}\text { Any economic activity using } \\
\text { the digital infrastructure, } \\
\text { technologies, services, and } \\
\text { data in the digital form as a } \\
\text { significant factor }\end{array}$ \\
\hline 3 & $\begin{array}{l}\text { At the broadest, overall definitions of the digital economy cover all digitally } \\
\text { enabled economic activity, including goods, software, infrastructure, services, } \\
\text { retail, and content (Bukht and Heeks, 2017). }\end{array}$ & $\begin{array}{l}\text { Inclusion of a manufacturing } \\
\text { sector (production of goods } \\
\text { of information and } \\
\text { communication technology) } \\
\text { in the structure of digital } \\
\text { economy }\end{array}$ \\
\hline 4 & $\begin{array}{l}\text { A digital economy is an economy that is based on electronic goods and } \\
\text { services produced by an electronic business and traded through electronic } \\
\text { commerce (Hojeghan and Esfangareh, 2011). }\end{array}$ & $\begin{array}{l}\text { Emphasis on electronic } \\
\text { goods and services as well as } \\
\text { e-commerce }\end{array}$ \\
\hline 5 & $\begin{array}{l}\text { The digital economy is defined as the segment of the economic output derived } \\
\text { primarily or solely from digitalized initiatives with organizational models } \\
\text { based on digital services or goods (Williams, 2021). }\end{array}$ & $\begin{array}{l}\text { Emphasis on the specific type } \\
\text { of economic products }\end{array}$ \\
\hline 6 & $\begin{array}{l}\text { Sharing information on environmental and social phenomena is at the heart of } \\
\text { the digital economy. To do so, we need a framework of technologies, } \\
\text { standards, organizational arrangements, and policies that makes it possible to } \\
\text { find, access, use, share, and publish such information (Prodanova et al., 2020). }\end{array}$ & $\begin{array}{l}\text { Emphasis on the exchange of } \\
\text { information as well as on the } \\
\text { infrastructure for its effective } \\
\text { transfer }\end{array}$ \\
\hline
\end{tabular}

1) Growth of competences of the population in the use of digital technologies. For example, about $50 \%$ of households worldwide have a personal computer (Alsop, 2021), and 62\% of the world population are Internet users (Meister et al., 2020).

2) Production digitalization. Digitalization allows production companies to manage difficult production processes (Kagermann et al., 2013) and opens new opportunities concerning efficiency, adaptability, and automation, thereby providing competitiveness and growth (Carolis et al., 2017). According to some estimates, Europe could achieve growth of as much as 1.25 trillion Euros in gross industrial value creation by 2025 (Eitner, 2021).

3) It is also necessary to recognize that the COVID-19 pandemic also became a serious push to the development of digital technologies in most of the industries.

Digitalization imposes some new requirements on the methods of management in organizations, such as the development of employee competences, change of motivation methods, and culture forming (Bencsik, 2020).

According to the research of the digitalization intensity level in various sectors of the economy, the highest level of digitalization is observed in transport equipment, telecommunications, IT and other information services, finance and insurance, legal and accounting activities, scientific research and development, advertising and other business services, and administrative and support services. The lowest level is observed in sectors such as agriculture, forestry, and fishing; mining and quarrying; food products, beverages, and tobacco; electricity, gas, steam, and air conditioning; water supply; sewerage, waste; construction; transportation and storage; accommodation and food service activities; and real estate (Calvino et al., 2018). In sectors such as agriculture, forestry, and fishing, the low level of digitalization seems to be natural, but in construction and real estate administration, such provision proves the need of the direction of investments and carrying out the research 
directed to the intensive implementation of digital technologies. There are two arguments to justify this position. First, construction is a significant part of the world economy, and $13 \%$ of the world's GDP are the share of the construction industry. The sector employs $7 \%$ of the world's working population (McKinsey, 2017). This means that the increase in efficiency that can be reached due to the digitalization of construction will have a global character. Second, modern construction is a difficult technology, and construction projects are information saturated. Work with such volumes of information with the traditional methods, without the greatest possible digitalization of processes, becomes less effective.

Building information modeling (BIM) is the basis of digitalization in construction (Wyman, 2018). The digital information model of a construction object results from the use of BIM technologies. The volume and quality of information, which is put in this model, allows the reduction of construction terms, the reduction of costs of materials, the avoidance of collisions, and, finally, the reduction of construction costs. The advantages of BIM application and the extent of the effect gained in practice are considered in the works of many scientists. Some of them studied the efficiency of BIM on the example of several large projects (Li et al., 2014; Olawumi and Chan, 2019), noting the change of indicators of work performance and cost. The results of the research that was devoted to the identification of the benefits of BIM to various stakeholders, which were obtained using sociological polls (Diaz, 2016; Al-Ashmori et al., 2020), were also provided. Studying the benefits of BIM, researchers place emphasis on various aspects. For example, they point out the substantial increase in the quality of information put into the project (Liu and Cao, 2021) and the decrease in the quantity of mistakes (that is the consequence of the high-quality project documentation) (Okakpu et al., 2019), which provides the common understanding of various project participants and increases the efficiency of their interaction, improvement of the project planning quality (Chen et al., 2011), and possibilities of the combined application of virtual and augmented reality technologies (Chai et al., 2019). Some researchers note that the use of BIM promotes a decrease in waste volume and provides effective use (Ganiyu et al., 2020). There are also studies that reveal the risks and obstacles of introducing BIM, in addition to the BIM benefits (Abiodun et al., 2020). However, they are usually focused on studying the design and construction stages. The research devoted to studying the advantages of BIM application during the maintenance stage is not enough (Heaton et al., 2019; Hu et al., 2018), and the research is mainly devoted to the engineering solutions, allowing one to use effectively information put into the information model of the building maintenance stage. The questions connected with the economic assessment of the advantages of BIM during the maintenance stage are still unsolved. It is possible to allocate several obstacles to BIM introduction: high implementation cost, considerable organizational and personnel transformations, and the lack of requirements from investors and customers.

A significant number of subjects participate in the implementation of construction projects. They are developers, contractors, managing companies, etc., in addition to the investor, the customer, and the designer. The maximum effect of BIM use can be gained when it is used during the whole life cycle of a construction project by all the involved participants. Concerning BIM-demanding investments, the question of assessing the cost efficiency of its introduction and use is relevant. At the moment, there is serious research devoted to assessing the cost efficiency of BIM during construction. However, as a rule, the maintenance stage is ignored, and that is done despite the fact that the maintenance stage is long and exceeds the construction term considerably. It makes, as a rule, 50 and more years. Also, the share of maintenance makes up $60-80 \%$ of the total cost of a real estate object. The use of $\mathrm{BIM}$ during the maintenance stage is capable of reducing the operating costs. This research 
is devoted to studying the conditions and valuation methods of the cost efficiency of the BIM application during the real estate object maintenance stage.

\section{Methods}

Development of the method of calculation of the economic effect of the BIM application is a rather difficult task. It is connected with the fact that BIM applications result in versatile benefits. They often have a noneconomic character, for example, the increase in the quality of work. It, in turn, influences the economic effect, but it is not so simple to define it. It is possible to refer to both the accumulation and storage of information in a digital format on the object for maintenance as benefits. When developing the methods of assessing the cost efficiency of BIM applications during the stage of real estate object maintenance, there are some research operations (Figure 1).

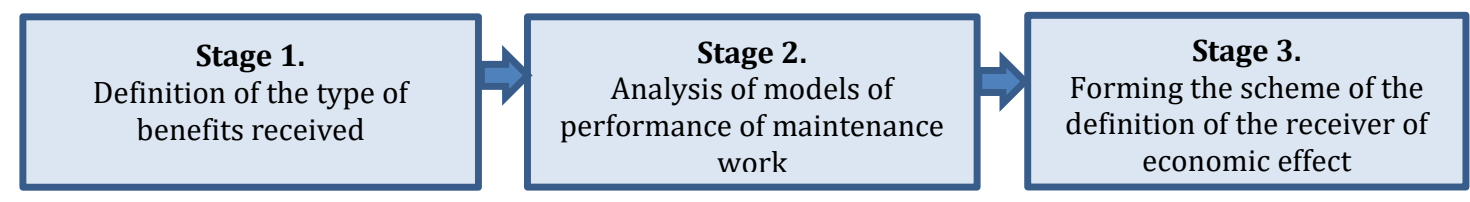

Figure 1 Sequence of steps according to the cost efficiency of BIM application during the stage of real estate object maintenance

At the first investigation phase, we define the type of benefits received during the maintenance stage. It was defined in previous research by the author that various project participants receive various benefits during different stages of the investment-and-construction project (Belkevich et al., 2019). Therefore, the main source of the economic effect during maintenance is reducing labor costs of the employees who are engaged in work on building maintenance. Tangible cost savings can also take place. Certainly, such a representation of benefits from the BIM application is too generalized and needs some specification.

The assessment of the economic effect of BIM during the real estate object maintenance stage requires observance of some conditions. Such an assessment will be complicated or impossible without them.

1. Availability of an organized accounting system in the organization that is engaged in real estate object maintenance. This assumes not only accounting of material costs but also all the other factors.

2. Exact evaluation of BIM application efficiency can be received only on the basis of comparison of the corresponding indicators without application of BIM and with BIM. Carrying out a comparison with the application of an object analog is possible for the maintenance organization. Otherwise, a comparison of indicators "before introduction" and "after introduction" is possible.

The known consulting company PwC (PricewaterhouseCoopers) created a multifactorial model of calculation of the economic effect of the BIM introduction for the projects in Great Britain, financed from the government budget (PwC, 2018). The model is accurately structured and proved. The author does not compete with it but offers her opinion.

During the second investigation phase (according to Figure 1), the author revealed the main models of performance of work on maintenance, applied in the practice of activity of the managing companies operating in the market. Therefore, it is possible to allocate two main models and their subspecies (Figure 2).

It is necessary to point out two directions for forming the economic effect of BIM application for its assessment:

1) Reduction of terms of work-the main source of the economic effect 
2) Tangible cost savings

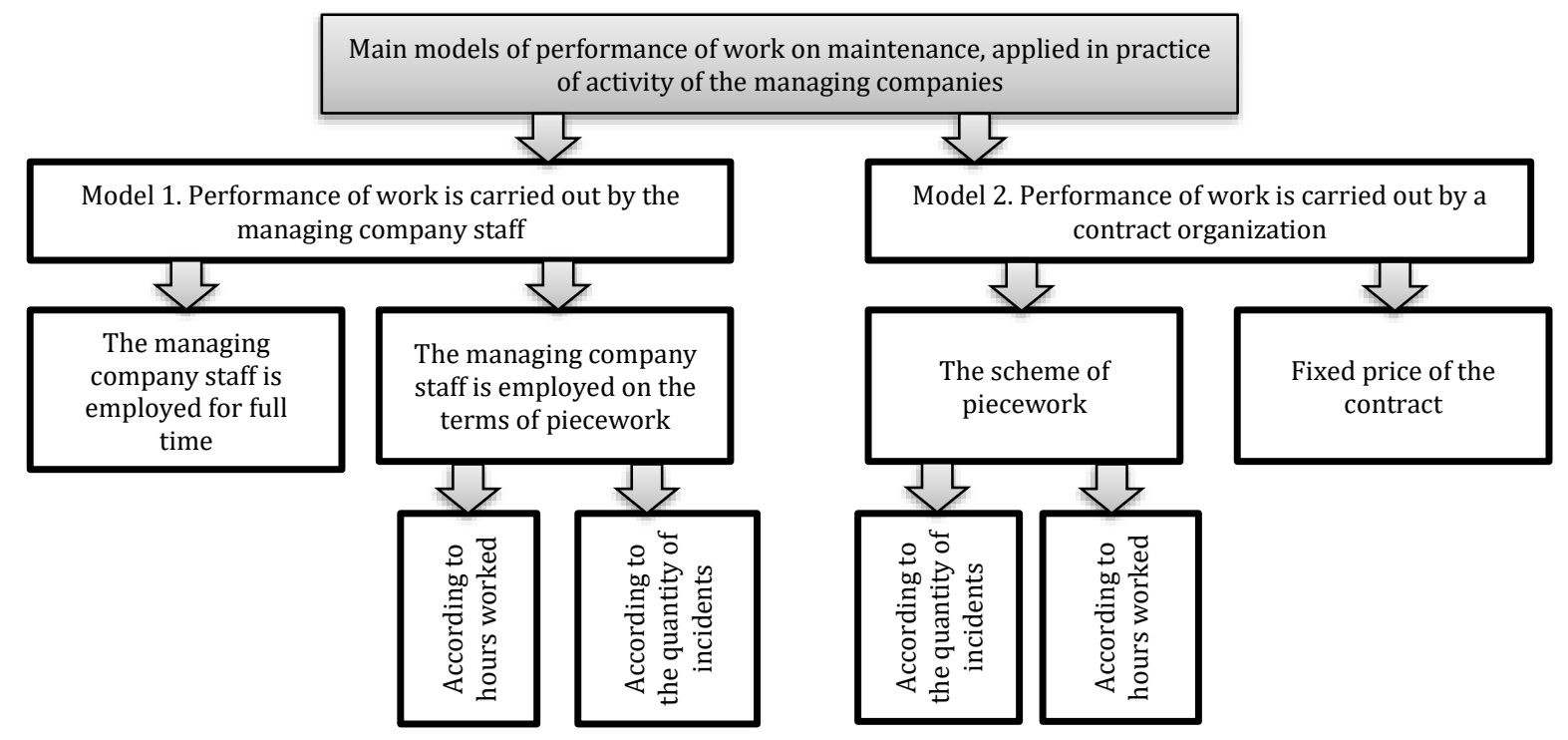

Figure 2 Main models of performance of work on maintenance, applied in the practice of activity of the managing companies operating in the market

The benefits connected with the reduction of work terms are the most significant during the maintenance stage.

There is an economy connected with the reduction of terms of maintenance and rescueand-recovery operations for the managing company (operating organization) that is engaged in the management of the real estate object.

This economy can be connected with the fastest identification of the reasons for technical problems, determination of the place of their emergence, and the choice of a method of their liquidation. The cost of rescue-and-recovery operations is, as a rule, estimated on the basis of their labor input in man-hours; therefore, it is offered to consider the economy of the managing company in these units. At the same time, the correction of technical problems and carrying out rescue-and-recovery operations can be carried out both by the staff of the managing company and the staff of contract organizations. It seems to be inexpedient to consider the economy on overheads of the managing company, as works on the management of the object are conducted in the permanent mode, regardless of carrying out any work on the object.

Thus, the economy of the managing company (MCE) in the most general form is offered to be counted according to the following Equation 1:

$$
M C E=\sum \Delta T \times C
$$

where $\Delta T$ is the change of terms of the rescue-and-recovery operation accomplishment and/or maintenance of these or those systems of the building (man-hours). It is considered separately for each type of work. $C$ is the cost of 1 man-hour of rescue-and-recovery operations or works on maintenance (calculated for each type of work separately according to their average market value, or relying on the standards developed by the managing company or contractors' quotations).

It is necessary to calculate total savings on all the carried-out types of work to assess the general amount of the economy (1). Such a method of calculation of the economy is theoretical. But, will it work in practice? If yes, how will it work?

During the third investigation stage, the analysis of the models of work, provided in Figure 2 , is carried out in terms of the features of forming an economic effect (as described in the 
Section 3). It is revealed that the real economy does not appear in certain cases and the potential recipient of economic effects also changes, depending on the applied work model. Proceeding from that, the author created the scheme of the definition of the receiver of the economic effect as a result of the research (presented in Section 3).

\section{Results and Discussion}

\subsection{Results}

As defined, there are several models of the performance of maintenance works. Depending on the applied model, it is also necessary to specify the methods of calculation of the cost economy:

Model 1. Performance of work is carried out by the management company staff:

1.1) The performance of work is carried out by the staff of the managing company. At the same time, the staff of the managing company is employed full time and receives their salary according to the rate that does not consider the amount of work.

In this case, the decrease in labor input of maintenance and rescue-and-recovery operations will not lead to any real economy of the budget of the managing company directly. However, the intensity of the employees' work will be less. It will be possible to speak about a real economy of the budget only if the reduction of labor input of work leads to the opportunity to lay off the number of the employees employed at the object. This means that the change of terms of accomplishment of rescue-and-recovery operations and/or maintenance of these or those systems of the building (in man-hours) has to reach a value of not less than 40 man-hours per week. We also consider that there can be versatile works. Therefore, these types of works should also be considered and grouped. The economy will be equal not only to the amount of the laid-off employees' salary but also to the amount of tax charges on their salary. Then, the formula for the calculation of the managing company economy (MCE) takes the following form (Equation 2):

$$
M C E=\sum_{1}^{k} N_{i}\left(S_{i}+T_{i}\right)
$$

where $N_{i}$ is the quantity of laid-off employees according to their categories, $S_{i}$ is the salary of the dismissed employees according to their categories, and $T_{i}$ is the payroll taxes of dismissed employees according to their categories.

Without having practical calculations and actual data, we can assume at the moment that a real economy cannot be reached at small objects. However, it will take place for large objects.

1.2) The performance of work is carried out by the managing company staff:

1.2.1) The performance of work is carried out by the managing company staff. At the same time, the managing company staff is employed on the terms of piece work (according to the number of fulfilled working hours). In this case, the decrease in labor input of maintenance and rescue-and-recovery operations will lead to the real economy of the budget of managing company directly. The direct use of formula 1 is possible for the economy calculation.

1.2.2) The performance of work is carried out by the managing company staff. At the same time, the managing company staff is employed on the terms of piece work (according to the number of incidents). In this case, the payment will be made according to the quantity of challenges of the employee for the work. Saving the employee's time for the accomplishment of transactions will not lead to the real economy of the budget of the managing company. However, it is possible to assume that in cases where the object was constructed on the basis of BIM use, 
the number of incidents demanding a challenge from the corresponding specialists will be less at the expense of the high-quality project documentation and high-quality carrying out of construction works. In this case, the economy can be calculated according to Equation 3; however, as noted in Section 2, carrying out such an assessment requires comparison with the object analog:

$$
M C E=\sum \Delta I \times S
$$

where $\Delta I$ is the decrease in the quantity of incidents. It is considered separately for each type of work. $S$ is the cost of work (the sum of the employee's salary) on elimination of the incident (according to the employment contract of the employee).

Model 2. The performance of work is carried out by a contract organization:

2.1) The performance of work is carried out by a contract organization according to the scheme of piece works. That is, the agreement provided a piece-work pay according to the number of fulfilled working hours according to the number of incidents.

2.1.1) In the case of piece-work pay according to the number of incidents, the contract organization becomes the recipient of the economy. The company receives payment for each incident, demanding the performance of work by its employees. The staff of the contract organization, having access to the information model for determination of the place of emergence of the incident and its reasons, perform work with time savings. The managing company obtains the high-quality performance of work by the contract organization but does not gain any economy of the budget funds. Here, the decrease in the number of incidents is also possible when the object was constructed on the basis of the BIM use. Economy can be calculated according to Equation 4; however, as noted in Section 2, carrying out the assessment requires comparison with the object analog:

$$
M C E=\sum \Delta I \times C
$$

where $\Delta I$ is the decrease in the quantity of incidents (separately for each work type) and $C$ is the cost of work on elimination of the incident (separately for each work type according to the contract terms).

2.1.2) In the case of piece-work pay according to the number of fulfilled working hours, the decrease in labor input of maintenance and rescue-and-recovery operations will lead to the real economy of the budget of the managing company directly and is calculated according to Equation 1.

2.2) Performance of work is carried out by contract organization on firm contract value. The types of the performed works are stipulated in the contract; however, their quantity is not defined. The employee or several employees of the contract organization are often in the permanent mode in the territory of the object in the case of such a contract. At the same time, the managing company receives the high-quality performance of work by the contract organization, but it does not receive any economy of the budget. Receiving economy by the contract organization can be determined by the principle described above in model 1.1 (Equation 2).

The scheme of the definition of the receiver of the economic effect from the use of information modeling technologies during the building maintenance stage, depending on the model of work, was created as the result of the conducted research (Table 2).

As for the decrease in material costs during the real estate object maintenance stage, it can also turn out to be the consequence of the high-quality project documentation and high- 
quality carrying out of the construction works in the case of the BIM application. If the number of incidents (breakages, etc.) decreases, then the amount of materials and equipment necessary for carrying out rescue-and-recovery operations will decrease.

Table 2 Receivers of the economic effect of BIM application (building maintenance stage)

\begin{tabular}{|c|c|c|c|}
\hline & \multirow{2}{*}{$\begin{array}{c}\text { Fixed Rate } \\
\text { (Fixed Price of the Contract for the Contract } \\
\text { Organization, Full Time for the Managing } \\
\text { Company Staff) }\end{array}$} & \multicolumn{2}{|c|}{ Piecework } \\
\hline & & $\begin{array}{l}\text { According to Hours } \\
\text { Worked }\end{array}$ & $\begin{array}{c}\text { According to the } \\
\text { Quantity of Incidents }\end{array}$ \\
\hline $\begin{array}{l}\text { Performance of work } \\
\text { is carried out by the } \\
\text { managing company } \\
\text { staff }\end{array}$ & $\begin{array}{l}\text { Managing company (in case when the reduction } \\
\text { in labor input of work leads to the opportunity } \\
\text { to lay off the quantity of the employees occupied } \\
\text { on the object) }\end{array}$ & Managing company & $\begin{array}{l}\text { Real budget saving will } \\
\text { not exist for the } \\
\text { management company }\end{array}$ \\
\hline $\begin{array}{l}\text { Performance of work } \\
\text { is carried out by a } \\
\text { contract organization }\end{array}$ & $\begin{array}{l}\text { Contract organization (in case when reduction } \\
\text { in labor input of work leads to the opportunity } \\
\text { to lay off the quantity of the employees occupied } \\
\text { on the object) }\end{array}$ & Managing company & Contract organization \\
\hline
\end{tabular}

The cost reduction is connected with the reduction of the work terms and with the decrease in material costs, and an economic effect can also be created in the field of overheads: cost of time for holding meetings, for listing of the materials, etc. All the necessary information will be available in electronic form in the information model.

Also, the BIM application during the real estate object maintenance stage leads to forming a whole range of effects. Agreeing with the PwC provisions offered in the technique, we can point out the increase in security and improvement of working conditions, risk reduction, improvement of quality of assets for the final user, and improvement of reputation.

\subsection{Discussion}

Studying of materials of the publications devoted to the identification of benefits of BIM application for various stakeholders (Diaz, 2016; Al-Ashmori et al., 2020) and during various stages of life cycle (Santos et al., 2020; Olanrewaju et al., 2021) allows us to conclude that they are generally accented on the allocation of factors and directions of the effect emergence, sometimes on the generalized conclusions on their assessment, but they are not directed to any practical assessment and do not offer any calculation models. Moreover, they do not place an emphasis on the economy during maintenance work.

The approach to the measurement of the economic effect of BIM introduction for the projects in Great Britain, financed from the state budget, developed by $\mathrm{PwC}(\mathrm{PwC}, 2018)$ is well-known at the moment. It contains some methodical recommendations on the calculation of the economic effect at all stages of a real estate object life cycle, including the maintenance stage or commissioning of the object for rent. Unlike the approach developed by $\mathrm{PwC}$, this research emphasizes the practical side of calculation and the search for the real receiver of the economy. This becomes possible due to the identification of the main models of work performance during maintenance, applied in the practice of activity of the management companies operating in the market. It makes the research results more concrete and convenient for application in practical activities.

\section{Conclusions}

Proceeding from the regulations that BIM can be used at all stages of the real estate object life cycle, the author tried to concretize the direction of obtaining benefits for different project participants during different stages. The author paid special attention to the stage of real estate object maintenance. The method of calculating the savings of a 
managing company from the application of the information model during real estate object maintenance is offered within the research. The author analyzed various models of maintenance work performance for refining the offered calculation procedure and considering its use in practice. The real economy of budget funds can arise or cannot arise depending on the used model of the maintenance work performance. Both a managing company and its contractors can also be the recipients of the economy depending on the model of the performance of work on maintenance.

The main direction of gaining the economy is the decrease in labor input of operations on maintenance and rescue-and-recovery operations. This leads to the cost reduction of time for the corresponding work and, respectively, to the reduction of costs connected with compensation. Also, the economy of material costs will take place. It is also necessary to consider the increase in the security and improvement of working conditions and risk reduction to calculate the cost efficiency of the application of BIM during the maintenance stage. The managing company also receives the improvement of reputation as a result of the application of BIM. However, it is difficult to estimate this benefit quantitatively.

\section{References}

Al-Ashmori, Y.Y., Othman, I., Rahmawati, Y., Amran, Y.H.M., Sabah, S.H.A., Rafindadi, A.D., 2020. BIM Benefits and Its Influence on the BIM Implementation in Malaysia. Ain Shams Engineering Journal, Volume 11(4), pp. 1013-1019

Alsop, T., 2021. Computer Penetration Rate among Households Worldwide 2005-2019. Available Online at https://www.statista.com/statistics/748551/worldwidehouseholds-with-computer/, Accessed on: August 22, 2021.

Belkevich, A., Dorobin, D., Emelyanov, I., Zobnin, M., Marinenkov, D., Skurikhin, L., Tuchkov, A., Tsvetkov, A., 2019. Guide to Information Modelling (BIM) for Customers on the Example of Industrial Facilities. Available Online at https://infrabim.csd.ru/upload/news/bim-standart-dlia-zakazchikovna\%20primere-promyshlennogo-obiekta.pdf, Accessed on August 20, 2021

Bencsik, A., 2020. Challenges of Management in the Digital Economy. International Journal of Technology, Volume 11(6), pp. 1275-1285

Bukht, R., Heeks, R., 2017. Defining, Conceptualising and Measuring the Digital Economy. International Organisations Research Journal, Volume 13(2), pp. 143-172

Calvino, F., Criscuolo, C., Marcolin, L., Squicciarini, M., 2018. A Taxonomy of Digital Intensive Sectors. OECD Science, Technology and Industry Working Papers, Volume 14, OECD Publishing, Paris

Carolis, A., Machhi, M., Negri, E., Terzi, S., 2017. A Maturity Model for Assessing the Digital Readiness of Manufacturing Companies. Advances in Production Management Systems. The Path to Intelligent, Collaborative and Sustainable Manufacturing. Springer International Publishing, pp. 13-20

Cassar, C., Heath, D., Micallef, L., 2010. What Is Digital Economy? Unicorns, Transformation and the Internet of Things. Available Online at https://www2.deloitte.com/mt/en/pages/technology/articles/mt-what-is-digitaleconomy.html, Accessed on August 22, 2021

Chai, C., Mustafa, K., Kuppusamy, S., Yusof, A., Lim, C.S., Wai, S.H., 2019. BIM Integration in Augmented Reality Model. International Journal of Technology, Volume 10(7), pp. 1266-1275

Chen, Y., Feng, C., Wang, Y., Wu, H., 2011. Using BIM Model and Genetic Algorithms to Optimize the Crew Assignment for Construction Project Planning. International Journal of Technology, Volume 2(3), pp. 179-187 
Diaz, P.M., 2016. Analysis of Benefits, Advantages and Challenges of Building Information Modelling in Construction Industry. Journal of Advances in Civil Engineering, Volume 2(2), pp. 1-11

Eitner, J., 2021. Digitalization Is Changing the Future of Manufacturing. Available Online at https://www.fraunhofer.de/en/research/current-research/production-4-0.html, Accessed on August 20, 2021

Ganiyu, S.A., Oyedele, L.O., Akinade, O., Owolabi, H., Akanbi, L., Gbadamosi, A., 2020. BIM Competencies for Delivering Waste-Efficient Building Projects in a Circular Economy. Developments in the Built Environment, Volume 4, https://doi.org/10.1016/j.dibe.2020.100036

Heaton, J., Parlikad, A.K., Schooling, J., 2019. Design and Development of BIM Models to Support Operations and Maintenance. Computers in Industry, Volume 111, pp. 172-186

Hojeghan, S.B., Esfangareh, A.N., 2011. Digital Economy and Tourism Impacts, Influences and Challenges. Social and Behavioral Sciences, Volume 19, pp. 308-316

Hu Z.-Z., Tian P.-L., Li, S.-W., Zhang, J.-P., 2018. BIM-based Integrated Delivery Technologies for Intelligent MEP Management in the Operation and Maintenance Phase. Advances in Engineering Software, Volume 115, pp. 1-16

Kagermann, H., Wahlster, W., Helbig, J., 2013. Recommendations for Implementing the Strategic Initiative INDUSTRIE 4.0: Securing the Future of German Manufacturing Industry. Final Report of the Industrie 4.0 Working Group. Forschungsunion, Acatech

Li, J., Wang, Y., Wang, X., Luo, H., Kang, S-C., Wang, J., Guo, J., Jiao, Y., 2014. Benefits of Building Information Modelling in the Project Lifecycle: Construction Projects in Asia. International Journal of Advanced Robotic Systems, Volume 11, pp. 1-11

Liu, Q., Cao, J., 2021. Application Research on Engineering Cost Management based on BIM. Procedia Computer Science, Volume 183, pp. 720-723

McKinsey, 2017. Global Institute, Reinventing Construction: A Route to Higher Productivity Meister, M., Metternich, J., Cviko, A., 2020. Definition of Problem Types for Planning Digitally Supported Problem-Solving Processes during Production Launch. Procedia CIRP, Volume 93, pp. 983-988

OECD, 2020. Report for the G20 Digital Economy Task Force: A Roadmap toward a Common Framework on Measuring the Digital Economy? Available Online at https://www.oecd.org/digital/ieconomy/roadmap-toward-a-common-frameworkfor-measuring-the-digital-economy.pdf, Accessed on August 25, 2021

Okakpu, A., Hoseini, A.G., Tookey, J., Haar, J., Hoseini, A.G., 2019. An Optimisation Process to Motivate Effective Adoption of BIM for Refurbishment of Complex Buildings in New Zealand. Frontiers of Architectural Research, Volume 8(4), pp. 646-661

Olanrewaju, O.I., Kineber, A.F., Chileshe, N., Edwards, D.J., 2021. Modelling the Impact of Building Information Modelling (BIM) Implementation Drivers and Awareness on Project Lifecycle. Sustainability, Volume 13(16), pp. 1-23

Olawumi, T.O., Chan, D.W.M., 2019. Building Information Modelling and Project Information Management Framework for Construction Projects. Journal of Civil Engineering and Management, Volume 25(1), pp. 53-75

Prodanova, N., Ahmetkalieva, S., Dabyltayeva, N., Kozhamkulova, Z., Yedilbayev, B., Abisheva, K., 2020. Model of Digital Economy. Central Asian Journal of Social Sciences and Humanities, Volume 2, pp. 53-58

Santos, R., Costa, A.G., Silvestre, J.D., Pyl, L., 2020. Development of a BIM-based Environmental and Economic Life Cycle Assessment Tool. Journal of Cleaner Production, Volume 265, https://doi.org/10.1016/j.jclepro.2020.121705

Williams, L.D., 2021. Concepts of Digital Economy and Industry 4.0 in Intelligent and 
Information Systems. International Journal of Intelligent Networks, Volume 2, pp. 122129

Wyman, O., 2018. Digitalization of the Construction Industry: The Revolution is Underway, Available Online at https://www.oliverwyman.com/content/dam/oliverwyman/v2/publications/2018/july/OliverWyman_Digitalization_in_the_construction _industry_web_final.PDF, Accessed on August 22, 2021 